ISSN 2409-2665

Journal of Logistics, Informatics and Service

Science Vol. 7 (2020) No. 1, pp. 67-86

DOI: 10.33168/LISS.2020.0106

\title{
From Business Modeling to Business Management: An Exploratory Study of the Optimal Decision Making on the Modern University Level
}

\author{
Ruizan Mekvabidze \\ Gori State Teaching University, 53 Chavchavadze ave., Georgia \\ gsu@grt.ge
}

\begin{abstract}
It is a fact that "The Fourth Industrial Revolution" is one of the main aspects of higher educational reforms, curricula changes, and knowledge formation. For graduates' it must be directed for the evolution of knowledge creation according to the competitive job market requirements. The Modern Digital Industrial Age and its impact on the orientation of education tend to reach substantial improvement of new generation learners and offer opportunities for the idea development for transforming research curricula with the main aspect: to develop good progression of integration knowledge and competencies of research for practice. Higher Education is a social investment and includes benefits from research and technological innovation with employed research methods to examine the expected professional level of university graduates. The scientific paper considers knowledge formation possibilities of graduates of Master of Business Administration and Management with specialization of management for the competitive job market and: classifies the main approaches for exploration of business modeling studying on the modern university-level concerning forming successful specialists, and to respond to the requirements of the modern competitive world, accordingly; analyzes the problems and issues of higher education with system dynamics of educational reforms institutional diversity, some directions are identified for knowledge creation (a program of research methods, students' motivation); assesses the impact on business and economics graduates' knowledge creation and its use in practice by them. Information for processing has been gained accordingly by the questionnaires of four categories with various indicators. There analyzed the data processing results and given conclusion and recommendation to improve the research program for MBA students with "model building" and optimization methods.
\end{abstract}

Keywords: exploratory study, optimal decision making, progression of integration knowledge, formation specialists, job market. 


\section{Introduction}

Information and more unified information space is a basis for the decision-making process and a crucial factor in the research process studying and can be used for the integration of knowledge of optimal decision-making in practice. As industrial age has taken place in recent years and analysis methods optimal managerial decisions are necessary for managers, they must learn to analyze and understand data concerning relevant variables and relationships and to make inferences and predictions based on such data (Mekvabidze, 2013).

The possibility to use data to drive decisions for modern management effectively includes using data for decision making with a discussion of different frameworks to support optimal decision-making, and questions (Mekvabidze,2016): What is the role of data in the research process for optimal decision making? What is the role research design for thinking for optimal decision making?

The new technology that rapidly occurring globally has a positive impact on graduates because of the arrival of new possibilities a creation and using of the unified information space (UIS) that and can be used as a tool for establishing meaningful projects to engage graduate students and educators in critical thinking and problem-solving. "In its scale, scope, and complexity, the transformation will be unlike anything humankind has experienced before" (Mekvabidze, 2015).

Today, we need to know that the new industrial age presents a modern set of challenges and address to improve higher education management. We cannot draw a picture, and we cannot research the problems without education development as education means growing of knowledge (Bakradze, 2013) after that, a country is ready to develop economics, business, healthcare, and so on. Education facilitates the acquisition of new skills and knowledge that increase productivity, which creates a new direction of country economic development in various ways.

\section{Literature Review}

Business involves different academic disciplines, such as mathematics, economics, sociology, psychology, etc., and when we decide to research business, we have to draw business research as a multi-disciplinary object. Business research is conducted with a purpose to understand: What do business want to find out? What are the arguments that need to be built about a concept?

In the Industry 4.0 , it is possible to combine different business models with customer access flexibly (e.g., production on demand; production on-site and consumer engineering) and thereby creating new kinds of production methods. Disruptive digital business models will focus on generating extra digital revenues and optimizing customer experience in terms of interaction and access (Didier Blanchet, Pauline Givord,2017). Big Data is today's technology hot topic. The term "Big Data" entered the mainstream vocabulary around 2010 when people became 
aware of the exponential rate at which data were being generated, primarily through the use of social media. Engineers and computer scientists quickly realized that Big Data could not be defined purely in terms of size. While it is undoubtedly true that the volume of data has increased by orders of magnitude over the past decade, other factors have changed the informational landscape as well. Big Data allows for better prediction of economic phenomena and improves causal inference (Jinjing Li et al., 2017).

Recently, industrial Big Data analytics has attracted extensive research interests from both Academia and Industry. Effective use of industrial Big Data analytics became a basic competition for today's business. The interest in The Fourth Industrial Age, which concerned with Big Data, considers many questions on combining, analyzing, and using them for any problem-solving. Such considerations and debates are documented (World Economic Forum, 2016), and among these questions, the question of how the data are used often debated in the educational area, also. Higher Education in the fourth industrial age potentially transformed not only society. It concerns higher education with its main characteristics teaching, Learning, research, and in this case, Big Data helped to develop Learning Analytics. It affects business, and Big Data helped to develop Business Analytics with statistical analysis, predictive modeling, optimization, and simulation. And more, the advent of Big Data is associated with the active development of new platforms and the improvement of the software. In result, Big Data helps us to understand better a range of issues of business decision problem research "...sets offer a higher form of intelligence and knowledge that can generate insights that were previously impossible, with the aura of truth, objectivity, and accuracy." (Acquisti, Gross2009).

Besides its, the decision-making support models are an excellent tool in situations involving technological changes and new, intelligent field of technology for process management is continuously being developed in the industry. The leading idea is to understand and assess the relationship between decision making art and technology development for successful realization management of business and economics through business research studying and new technology (Mekvabidze, 2016).

Decision analysis functions at four different levels as a philosophy, as a decision framework, as a decision-making process, and as a decision-making methodology — and each level focuses on various aspects of the problem of making decisions (Mcname, Celona, 2008). This approach is a useful and powerful management tool for economists and business makers. However, it is a central task of managerial economics that considers business makers' problems through using systems analysis and operations research. This is a reason that nowadays, the focus is on very complex and integrated decision-making systems.

In the era of the new industry of technology will play a more significant part in optimizing solutions. Making the right decision is only validated by the results. But 
in the new technology age, decision making and its optimization have become more challenging due to the exponential growth and access to information. Optimization of decision making is an essential skill required for any manager as a competent decision-maker is a talent that can be gained through years of practice. A leader can make any decision, but what matters more is effective decision-making that provides for a positive outcome. A Harvard study came up with a list of characteristics that are correlated with ethical decision making (positive outcomes), as technology becomes an essential factor in decision making. As a result, decisionmakers should consider bringing in outside expertise if there is no in-house expertise to help clarify the technology in context with the problem (Davenport, Patil 2012).

Today, optimal decision-making has to be included in the research studying process where the role of technology in optimal decision making comprises. As a result, using of new technology should be as a key to enriching the business research program, which will be directed to gain the competitive skills and knowledge for the labor market requirements (Provost, Fawcett,2013).

A graduate, as the decision-maker in the future, if he wants to achieve optimum results in decision-making and operations, by accomplishing set tasks, must take into account the use of new, modern market trends of progress and development new approaches and upgrade them in everyday business processes. The role of information systems in decision making is organized to support the data processing, office automation, management, decision-making and reporting as the new technologies primarily affect the development and emergence of new tools, models, methods, techniques and systems that are tailored to customer requirements, and decision-makers (Elgend, 2016).

Based on the OECD report, we can discuss the skills required for success by using the Industry 4.0 environment and predict the higher universities' development in the future where we have to considered collaboration between universities, industry, and public bodies. Besides, life requires working and communicating with people from different backgrounds and understanding the possibility to learn and find new solutions to increasingly complex challenges. The competencies related to management, in this case, are technology awareness, change management, and using forecasting data and planning metrics for strategy development (David, 2016). As the world becomes more connected and dependent on natural and intellectual resources and educational university requirements across the globe have increased, we explore closely linked questions to the international and global level research and understanding for sustainability challenges faced by global socio-scientific issues and the globalization of education. Obviously, "it becomes impossible to consider contemporary education in isolation from globalization as the dominant logic and rethinking social and cultural life in which it is located" (Mekvabidze R., Mekvabidze P., 2009). 
One crucial question to be investigated is the quality program of research studying. Developing globalization helps to formulate new questions and methods to examine these questions with opportunities to expand the conceptual and analytical sides. The main direction has to engage graduates in the study program considering student's employment problems but the matters are arising: Is the graduate student ready for this process? Could the students handle modern complex systems? What is the relationship between the indicators of research studying and practice? (Mekvabidze, 2015).

In a rapidly changing world, rethinking the issues of $\mathrm{HE}$ universities is addressed to the problems of severe political conflict and potential social disruption. Quality educational programs play a crucial role in the development of the workforce for the competitive job market and preparing students for life. The main essential issues are providing quality business research programs responses to global economic restructuring, and specialization and integration of research and practice with gain the job experience (Mekvabidze, 2015).

The analysis focuses on areas of acute crisis within the EU universities, too: issues over the curricula, concerns over the academic freedom, issues over the regulation of the research methods studying, and issues over the integration of the research studying with practice by the requirements of the job markets. Such problems are considered in Baker and Lenhardt research (Baker, Lenhardt, 2008): "The ongoing crisis of the German university illustrates the potential difficulties with implementing the emerging global model (EGM) of the new research university in a nation where there is a long tradition of higher education". Also, these problems take place if we consider this problem in a broad sense, as Shapiro states in his research too (Shapiro, 2009). In the New Industrial Revolution Era education faces many critical issues in the frame of the current educational reforms and the more significant questions should be formulated as are: How and when we can solve them? What should we do for it? The different opportunities and challenges for Higher Education systems require specific skills for 2020 vs. 2015. In 2020, the first place takes "Complex approaches and problem-solving" again, and this result indicates that higher education far from the implementation of new industrial technology. One of the versions to improve this situation to transform research studying at the MBA level (World Economic Forum, 2016).

\section{Research Methodology}

By the review, the content of the syllabuses of the discipline "Business research methods and models" syllabuses most of the European universities and books on this theme include business statistics material that can be considered as the prerequisite material mostly for this discipline. In this case, it is interesting to find two main questions: what types of analysis can be conducted and what kinds of analysis can be used for improving the studying on the need level (Snyder, 2019). 
Business research methods teaching process include business statistics material and for its teaching is spending $2 / 3$ all of the teaching hours or more by the EU universities. MA students do not reach the need basis for knowledge capacity, and as a result, they are less competitive for the job market. This is why changes and improvement research program or introduction new disciplines or enrich research material is necessary.

Businesses have moved from individual business functions towards optimizing the entire business process, as called business process reengineering. It has arisen under information technology and the trend towards globalization. Hence, business process performance is one of the sources of competitive advantage nowadays. It means that it has to be changed business research studying procedure as research is a basis of business modeling, business management, and operation management. Graduate's knowledge and practical skills must be concerning business functions toward its optimization with the management decision-making process, operations research, and powerful technique in practice today. To improve business decisions by optimization methods, it means: data integration and analytics, how to formulate and solve complex optimization models, and to incorporate risk management concerns.

Master of Business Administration and Management (MBAM) students' as the participants in the learning process, can manage their own Learning and are able to appropriate learning goals to use their existing knowledge skills and strategies to direct job market requirements. Therefore, students have to understand and develop strategies that will best enhance knowledge that can be structured as a model - these modelers close to the process and modern technologies. The programs for formation specialists for business have to include studying material on models' building for decision making, business process optimization, and business process management as employers look for such specialists.

Today, it is necessary to examine various approaches that promote students' knowledge improvement to respond to job markets in the future. In the frame of the modern educational reforms have to be realized student's active engagement in Learning that provides them with the need skills and prepares them to meet the challenges and changes occurring in the workplace competently. The objectives of the research framework are: to draw the student's objective for knowledge creation to business analytics, business model building with optimal decision making for the competitive job market; to bring the approaches of academics and teachers of the need to transform the program of training in business research, taking into account new technologies and the competitive job markets.

The research framework, based on the practical approaches to the competitive job market and curricula of MBAM on a higher university level, five variables were considered as dependent variables on various factors: business research methods and models' teaching with the 6 indicators; business research methods' and models' 
Learning with 8 indicators; knowledge creation through research approaches with the 12 indicators; knowledge creation through research with practice with 8 indicators; and knowledge creation for business research studying according to the job market, 21 indicators.

This study will be examined the effect of these variables on the dependent variable, which is knowledge creation with capacity for the job market. The study seeks the behavior of faculties and students by their answers accordingly. In the frame of the research was conducted: preparing two questionnaires for the academics and students separately; research design; research instrumentation; data collection by questionnaires according to the sample size; data processing using STATA; analysis; discussion; conclusion.

Three criteria usually will need to the specified to determine the appropriate sample size: the level of precision, the level of confidence, the degree of variability. The sample size was calculated by using the Taro Yamane formula (A case of the finite population). $\mathrm{n}=\mathrm{N} /\left[1+\mathrm{N}(\mathrm{e})^{\wedge} 2\right]$ where: $\mathrm{n}$ - sample size; $\mathrm{N}$ - population size (the universe); e - the acceptable sampling error.

The study developed two types of surveys design for academics and students. The samples are formed from the various categories and were considered: three groups of faculty members (Professors, Ass. Professors, Invited teachers). Developing questionnaires as the data-gathering tool (108 copies) was collected. All copies were not returned, giving a response $83 \%$. MBA students from Economics, business administration, and management were selected. Developing questionnaires as the data-gathering tool (130 copies) was spread. All copies were returned, giving a response of $100 \%$. Developing questionnaires used as a survey tool for this study was made with the various number of items into different sections. But they are identically for the students and the academics. The response options are: Strongly agree (SA), Agree (A), Neutral (N), Disagree (DA), Strongly Disagree (SD). The tests were carried out at the 0.05 level of significance.

\section{Discussion of Findings}

The Response of academics and students according to the research indicators. Regarding research results, the respondents were: the academics (108 persons) and the students (130 persons). Both were answered on the same research indicators. Demographic information about respondents is given in Table 1.

The responses of academics and teachers (108 respondents) are given in Tables 2-5 according to the indicators with $6,8,12,8$, accordingly, with various answers: strongly agree (SA), agree (A), neutral (N), disagree (DA), and strongly disagree (SDA). In Table 6 with 21 indicators are placed the sum of positive answers: strongly agree (SA), agree (A) and we call it "Yes" and the sum of negative answers: disagree (DA) and strongly disagree (SDA) and we call it "No". The results are placed in Table 6 . The answers "neutral $(\mathrm{N})$ " on the indicators are ignored. 
Table 1: Demographic information

\begin{tabular}{|c|c|c|c|}
\hline $\begin{array}{c}\text { Demographic } \\
\text { categories }\end{array}$ & Classification & Frequency & \% \\
\hline \multirow{3}{*}{ Gender } & F (teacher) & 62 & 57.4 \\
& M(teacher) & 46 & 42.6 \\
& F(student) & 73 & 56.2 \\
& M(student) & 57 & 43.8 \\
\hline \multirow{5}{*}{ Status } & Invited teacher & 28 & 25.9 \\
& Ass. Professor & 51 & 47.2 \\
& Professor & 29 & 26.9 \\
& The 1st year MBAM & 72 & 55.4 \\
& student & 58 & 44.6 \\
& 2nd-year MBAM student & & 9.3 \\
& Above 20 & 10 & 20.4 \\
Teaching & Years: 15-20 & 22 & 24.1 \\
experience & Years: 11-15 & 26 & 18.5 \\
& Years: 5-10 & 20 & 27.7 \\
\hline
\end{tabular}

Identically, the responses of MBAM students' (130 respondents) are given in Tables 6-10 according to the indicators with 8,12, 8, 6 accordingly, with various answers: strongly agree (SA), agree (A), neutral (N), disagree (DA), and strongly disagree (SDA). In Table 11 with 21 indicators are placed the sum of positive answers: strongly agree (SA), agree (A) and we call it "Yes" and the sum of negative answers: disagree (DA) and strongly disagree (SDA) and we call it "No". results are placed in Table 11. The answers "neutral $(\mathrm{N})$ " on the indicators are ignored.

STATA provides data processing of the results of Table 6 and Table 11. The results are presented in Figure 1. Such designations were identified:

- Yes_Academics - positive answers of the academics on the indicators (Table $6)$;

- Yes_Students - positive answers of the Students on the indicators (Table 11);

- NO_Academics - negative answers of the academics on the indicators (Table $6)$;

- NO_Students - negative answers of the students on the indicators (Table 11). 


\begin{tabular}{|c|c|c|c|c|}
\hline \multicolumn{2}{|c|}{ Mean estimation } & \multicolumn{2}{|c|}{ Number of obs } & $=\quad 21$ \\
\hline & Mean & Std. Err. & [95\% Conf. & Interval] \\
\hline Yes_Academ s & 75.95238 & 2.252487 & 71.25378 & 80.65099 \\
\hline \multicolumn{5}{|c|}{ - mean Yes_Students } \\
\hline \multicolumn{2}{|c|}{ Mean estimation } & \multicolumn{2}{|c|}{ Number of obs } & 21 \\
\hline & Mean & Std. Err. & [95\% conf. & Interva1] \\
\hline Yes_Students & 71.21095 & 2.217637 & 66.58504 & 75.83686 \\
\hline \multicolumn{5}{|c|}{ - mean NO_Academics } \\
\hline \multicolumn{2}{|c|}{ Mean estimation } & \multicolumn{2}{|c|}{ Number of obs } & 21 \\
\hline & Mean & Std. Err. & [95\% Conf. & Interval] \\
\hline NO_Academics & 24.04762 & 2.252487 & 19.34901 & 28.74622 \\
\hline \multicolumn{5}{|c|}{ - mean NO_Students } \\
\hline \multicolumn{2}{|c|}{ Mean estimation } & \multicolumn{2}{|c|}{ Number of obs } & 21 \\
\hline & Mean & Std. Err. & [95\% Conf. & Interval] \\
\hline NO_Students & 10.84 & 1.728637 & 7.234125 & 14.44587 \\
\hline
\end{tabular}

Fig. 1: Results of analysis (integration of Table 6 and Table 11)

As we see, both the academics and students agree on transforming the MBAM business research studying program with business process modeling aspects that take a central place to the business process solving with operations research and management science with 0.05 significance level. From the student's perspective, a mean of the positive answers is 71.21095, Std. error - 2.217637. From the academics' perspective, a mean of the positive answers is 75.95238 , Std. error 2.252487 .

\section{Conclusion}

In The general idea of the work was to show a vision of the academics and MBAM students on the possibilities for transformation of the business research studying program with using the technique of new industrial age for business research knowledge creation according to the competitive job market and the requirements of employers which look for the need specialists with experience and ability in they recruit.

In the research were involved academics (108 respondents) and MBAM students (130 respondents), which responded to the questions of the various categories. The study was based on the practical approaches to the competitive job 
market and curricula of MBAM on a higher university level. Five variables were considered as dependent variables on various factors: business research methods and models' teaching with the 6 indicators; business research methods' and models" Learning with 8 indicators; knowledge creation through research approaches with the 12 indicators; knowledge creation through research with practice with 8 indicators; and knowledge creation for business research studying according to the job market, 21 indicators.

Based on the research results, both the academics and students agree on transforming the MBAM business research studying program for knowledge creation according to the job market with 0.05 significance level with business process modeling aspects that take a central place to the business process solving with operations research and management science.

\section{References}

Acquisti, A. and Gross, R. (2009). Proceedings of the National Academy of Sciences of the United States of America, 06. https://doi.org/10.1073/pnas.0904891106

Baker D., Gero Lenhardt. (2008). Institutional Crisis of the German University. Higher Education Policy, 21, 49-64.

Bakradze L. (2013). Strategic Development of Higher Education and a Science - Integration of Teaching and Research. Tbilisi: The International Institute of Education Policy, Planning and Management (EPPM). https://eppm.org.ge/en/

Didier Blanchet, Pauline Givord. (2017). Big Data, official statistics and measuring the economy. L'economie Francaise, 59-76.

Fred R. David, (2016). Strategic Management: A competitive Advantage, Approaches, Concepts and cases. $16^{\text {th }}$ edition, Pearson.

Harold T. Shapiro. (2009). Higher Education and Society. UNESCO 2009 World Conference on Higher Education. Pub. SIDA/SAREC.

Hannah Snyder. (2019). Literature review as a research methodology: An overview and guidelines. Journal of Business Research,104: 333-339. 
Jinjing Li et al. (2018). Big Data in Tourism Research: A Literature review. Journal TOURMAN. https://doi.org/10.1016.

Mekvabidze R. (2013). Responding tomorrows world - following educational reforms in Georgia: Studying trends of transformation of economic education. 5th International conference on education and new learning technologies Barce technologies. Barcelona,1-3.

Mekvabidze R. (2016). The knowledge triangle as a main educational aspect of learning outcome. Scientific Papers of Berdyansk State Pedagogical University. Series: Pedagogical sciences, Issue 2. Berdyansk, 126-132.

Mekvabidze R. (2015). Approaches to the Modern University: Student Engagement in Learning Outcome for Knowledge Creation According to the Competitive Market Requirements. Journal of System and Management Science, (5:4), 1-30.

Mekvabidze R. (2016). Decision Making Technology in Practic. $1^{\text {st }}$ edition. Publisher: Universal, Tbilisi.

Mekvabidze R., Mekvabidze P. (2009). The Aspects of Globalization Economic Process. International-Scientific Conference: Globalization, World Crisis and South Caucasus, 16-17 May, Pub. Innovation, 82-87.

Mekvabidze R. (2015). Study Module: Business process Modeling. The $1^{\text {st }}$ edition, Universal, Tbilisi.

Peter Mcname, and John Celona. (2008). Decision analyses for the professionals. SmartOrg, ISBN 0-9710569-0-0.

Provost, F., and Fawcett Tom. (2013) . Data Science and Its Relationship to Big Data and Data-Driven Decision Making. DOI: 10.1089/big.2013.1508.

Thomas H. Davenport and D.J. Patil. (2012). Data scientist: The sexiest job of the $21^{\text {st }}$ century. Harvard Business review. http://hbr.org/2012/10/datascientist-the-sexiest-job-of-the- $21^{\text {st }}$-century. 


\section{World Economic Forum (2016).}

https://www.weforum.org/agenda/2016/01/the-10-skills-you-need-to-thrivein-the-fourth-industrial-revolution/.

\section{Appendixes}

Table 2: Influence of the fourth industrial age: The academics according to the

knowledge creation through Business research methods' and models' Teaching

\begin{tabular}{|c|c|c|c|c|c|c|}
\hline \multirow{2}{*}{ Variable } & \multirow{2}{*}{ Indicators } & \multicolumn{5}{|c|}{ Frequency and \% } \\
\hline & & SA & $\mathbf{A}$ & $\mathbf{N}$ & DA & SD \\
\hline \multirow{6}{*}{ 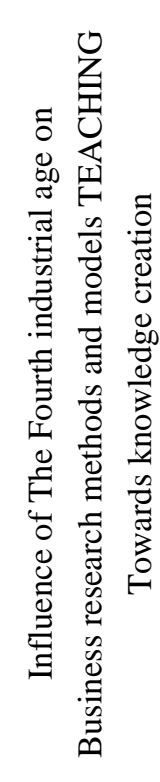 } & $\begin{array}{l}\text { Transfer of research methods and models } \\
\text { knowledge to learners may be provided through } \\
\text { the teaching of research methods and models }\end{array}$ & $\begin{array}{c}30 \\
28 \%\end{array}$ & $\begin{array}{c}61 \\
56 \%\end{array}$ & $\begin{array}{c}13 \\
12 \%\end{array}$ & $\begin{array}{c}4 \\
4 \%\end{array}$ & $\begin{array}{c}0 \\
0 \%\end{array}$ \\
\hline & $\begin{array}{l}\text { Business research views are respected to } \\
\text { research methods and models' building }\end{array}$ & $\begin{array}{c}19 \\
18 \%\end{array}$ & $\begin{array}{r}66 \\
61 \%\end{array}$ & $\begin{array}{c}23 \\
21 \%\end{array}$ & $\begin{array}{c}0 \\
0 \%\end{array}$ & $\begin{array}{c}0 \\
0 \%\end{array}$ \\
\hline & $\begin{array}{c}\text { Transfer of "model building" knowledge to } \\
\text { learners may be provided through teaching and } \\
\text { other mediums with research and research } \\
\text { practice }\end{array}$ & $\begin{array}{c}47 \\
44 \%\end{array}$ & $\begin{array}{c}45 \\
42 \%\end{array}$ & $\begin{array}{c}7 \\
6 \%\end{array}$ & $7 \%$ & $\begin{array}{c}1 \\
1 \%\end{array}$ \\
\hline & $\begin{array}{l}\text { Models' building Knowledge views with } \\
\text { respect to research and decision making } \\
\text { teaching link }\end{array}$ & $\begin{array}{c}48 \\
44 \%\end{array}$ & $\begin{array}{c}42 \\
39 \%\end{array}$ & $\begin{array}{c}15 \\
14 \%\end{array}$ & $\begin{array}{c}3 \\
3 \%\end{array}$ & $\begin{array}{c}0 \\
0 \%\end{array}$ \\
\hline & $\begin{array}{l}\text { Transfer of business knowledge responds to } \\
\text { research methods and models building }\end{array}$ & $\begin{array}{c}29 \\
27 \%\end{array}$ & $\begin{array}{c}52 \\
48 \% \\
\end{array}$ & $\begin{array}{c}20 \\
19 \%\end{array}$ & $\begin{array}{c}4 \\
4 \% \\
\end{array}$ & $\begin{array}{c}3 \\
3 \%\end{array}$ \\
\hline & $\begin{array}{l}\text { Business research have to responds business } \\
\text { process optimization }\end{array}$ & $\begin{array}{c}44 \\
42 \%\end{array}$ & $\begin{array}{c}47 \\
45 \%\end{array}$ & $\begin{array}{c}8 \\
8 \%\end{array}$ & $\begin{array}{c}5 \\
5 \%\end{array}$ & $\begin{array}{c}0 \\
0 \%\end{array}$ \\
\hline
\end{tabular}

Table 3: Influence of the fourth industrial age: The academics according to the knowledge creation through Business research methods' and models' Learning

\begin{tabular}{|c|c|c|c|c|c|c|}
\hline \multirow{2}{*}{ Variable } & \multirow{2}{*}{ Indicators } & \multicolumn{5}{|c|}{ Frequency and \% } \\
\hline & & SA & $\mathbf{A}$ & $\mathbf{N}$ & DA & SD \\
\hline \multirow{4}{*}{ 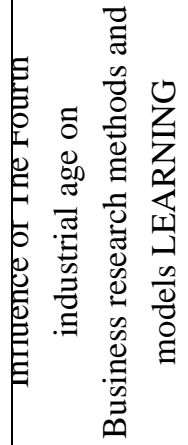 } & $\begin{array}{l}\text { Critical thinking stimulate students' to provide } \\
\text { them for research and knowledge creation }\end{array}$ & $\begin{array}{c}22 \\
20 \%\end{array}$ & $\begin{array}{c}33 \\
31 \%\end{array}$ & $\begin{array}{c}25 \\
23 \%\end{array}$ & $\begin{array}{c}18 \\
17 \%\end{array}$ & $\begin{array}{l}10 \\
9 \%\end{array}$ \\
\hline & $\begin{array}{l}\text { Model building teaching is suggested by many } \\
\text { pedagogical researchers as the most effective } \\
\text { for MA student's learning process }\end{array}$ & $\begin{array}{c}25 \\
23 \%\end{array}$ & $\begin{array}{c}37 \\
34 \%\end{array}$ & $\begin{array}{c}33 \\
31 \%\end{array}$ & $\begin{array}{l}10 \\
9 \%\end{array}$ & $\begin{array}{c}3 \\
3 \%\end{array}$ \\
\hline & $\begin{array}{l}\text { Effective strategy for knowledge creation is a } \\
\text { model building research into teaching }\end{array}$ & $\begin{array}{c}34 \\
31 \%\end{array}$ & $\begin{array}{c}56 \\
52 \%\end{array}$ & $\begin{array}{c}8 \\
7 \%\end{array}$ & $\begin{array}{c}9 \\
8 \%\end{array}$ & $\begin{array}{c}1 \\
1 \%\end{array}$ \\
\hline & $\begin{array}{l}\text { Operation Research into teaching as a } \\
\text { knowledge transfer for job market }\end{array}$ & $\begin{array}{c}37 \\
34 \%\end{array}$ & $\begin{array}{c}43 \\
40 \%\end{array}$ & $\begin{array}{c}22 \\
20 \%\end{array}$ & $\begin{array}{c}5 \\
5 \%\end{array}$ & $\begin{array}{c}1 \\
1 \%\end{array}$ \\
\hline
\end{tabular}




\begin{tabular}{|c|c|c|c|c|c|c|}
\hline & & & & & \\
\cline { 2 - 6 } & Teaching interact with new research & 34 & 53 & 16 & 3 & 2 \\
approaches studying & $31 \%$ & $49 \%$ & $15 \%$ & $3 \%$ & $2 \%$ \\
\cline { 2 - 6 } & Business Research interacts with business & 28 & 47 & 26 & 5 & 1 \\
modeling & $26 \%$ & $44 \%$ & $24 \%$ & $5 \%$ & $1 \%$ \\
\cline { 2 - 6 } & Business Research into teaching as a business & 36 & 53 & 13 & 5 & 1 \\
knowledge transfer process & $33 \%$ & $49 \%$ & $12 \%$ & $5 \%$ & $1 \%$ \\
\cline { 2 - 6 } & Research into teaching should not be a separate & 42 & 46 & 12 & 8 & 0 \\
& process & $39 \%$ & $43 \%$ & $11 \%$ & $7 \%$ & $0 \%$ \\
\hline
\end{tabular}

Table 4: Influence of the fourth industrial age: The academics according to the knowledge creation through RESEARCH APPROACHES

\begin{tabular}{|c|c|c|c|c|c|c|}
\hline \multirow{2}{*}{ Variable } & \multirow{2}{*}{ Indicators } & \multicolumn{5}{|c|}{ Frequency and \% } \\
\hline & & $\mathbf{S A}$ & $\mathbf{A}$ & $\mathbf{N}$ & DA & SD \\
\hline \multirow{11}{*}{ 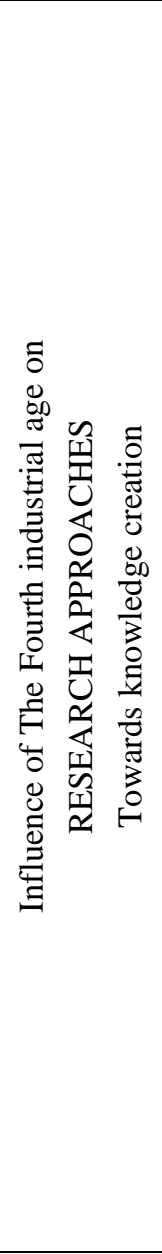 } & $\begin{array}{c}\text { Research Knowledge is a basis for all students } \\
\text { - certainly all graduates - have to be } \\
\text { researchers and managers }\end{array}$ & $\begin{array}{c}35 \\
32 \%\end{array}$ & $\begin{array}{c}50 \\
46 \%\end{array}$ & $\begin{array}{c}18 \\
17 \%\end{array}$ & $\begin{array}{c}4 \\
4 \%\end{array}$ & $\begin{array}{c}1 \\
1 \%\end{array}$ \\
\hline & $\begin{array}{c}\text { Knowledge of business research studying } \\
\text { interact with teaching modeling, optimization } \\
\text { and research practice }\end{array}$ & $\begin{array}{c}26 \\
24 \%\end{array}$ & $\begin{array}{c}53 \\
49 \%\end{array}$ & $2725 \%$ & & $\begin{array}{c}0 \\
0 \%\end{array}$ \\
\hline & $\begin{array}{l}\text { A movement of knowledge to learners may be } \\
\text { provided through teaching and other mediums } \\
\text { with research and practice }\end{array}$ & $\begin{array}{c}34 \\
31 \%\end{array}$ & $\begin{array}{c}63 \\
58 \%\end{array}$ & $\begin{array}{c}5 \\
5 \%\end{array}$ & $\begin{array}{c}3 \\
3 \%\end{array}$ & $\begin{array}{c}3 \\
3 \%\end{array}$ \\
\hline & $\begin{array}{l}\text { Quality business research studying improves } \\
\text { student's skills for the job market }\end{array}$ & $\begin{array}{c}32 \\
30 \% \\
\end{array}$ & $\begin{array}{c}54 \\
50 \% \\
\end{array}$ & $\begin{array}{c}15 \\
14 \% \\
\end{array}$ & $\begin{array}{c}4 \\
4 \% \\
\end{array}$ & $\begin{array}{c}3 \\
3 \%\end{array}$ \\
\hline & $\begin{array}{l}\text { Teaching of Optimization interact with } \\
\text { business research }\end{array}$ & $\begin{array}{c}29 \\
27 \% \\
\end{array}$ & $\begin{array}{c}45 \\
42 \% \\
\end{array}$ & $\begin{array}{c}26 \\
24 \% \\
\end{array}$ & $\begin{array}{c}6 \\
6 \% \\
\end{array}$ & $\begin{array}{c}2 \\
2 \% \\
\end{array}$ \\
\hline & All academics have to be good researchers & $\begin{array}{c}30 \\
28 \%\end{array}$ & $\begin{array}{c}37 \\
34 \% \\
\end{array}$ & $\begin{array}{c}24 \\
22 \% \\
\end{array}$ & $\begin{array}{r}10 \\
9 \%\end{array}$ & $\begin{array}{c}7 \\
6 \% \\
\end{array}$ \\
\hline & $\begin{array}{l}\text { Research as a generator of knowledge } \\
\text { management }\end{array}$ & $\begin{array}{c}32 \\
30 \% \\
\end{array}$ & $\begin{array}{c}54 \\
50 \%\end{array}$ & $\begin{array}{c}17 \\
16 \% \\
\end{array}$ & $\begin{array}{c}3 \\
3 \% \\
\end{array}$ & $\begin{array}{c}2 \\
2 \% \\
\end{array}$ \\
\hline & $\begin{array}{c}\text { Business Research into teaching as a } \\
\text { knowledge transfer process }\end{array}$ & $\begin{array}{c}34 \\
31 \% \\
\end{array}$ & $\begin{array}{c}57 \\
53 \% \\
\end{array}$ & $\begin{array}{c}16 \\
15 \% \\
\end{array}$ & $\begin{array}{c}1 \\
1 \% \\
\end{array}$ & $\begin{array}{c}0 \\
0 \% \\
\end{array}$ \\
\hline & $\begin{array}{l}\text { Business modeling research into teaching } \\
\text { should not be a separate process }\end{array}$ & $\begin{array}{c}23 \\
21 \% \\
\end{array}$ & $\begin{array}{c}36 \\
33 \% \\
\end{array}$ & $\begin{array}{c}35 \\
32 \% \\
\end{array}$ & $\begin{array}{c}13 \\
12 \% \\
\end{array}$ & $\begin{array}{c}1 \\
1 \%\end{array}$ \\
\hline & $\begin{array}{l}\text { For MBAM teaching interact with research } \\
\text { modeling }\end{array}$ & $\begin{array}{c}12 \\
11 \%\end{array}$ & $\begin{array}{c}44 \\
41 \% \\
\end{array}$ & $\begin{array}{c}23 \\
21 \% \\
\end{array}$ & $\begin{array}{c}24 \\
22 \%\end{array}$ & $\begin{array}{c}5 \\
5 \% \\
\end{array}$ \\
\hline & $\begin{array}{l}\text { Knowledge should flow from teaching to } \\
\text { research approaches }\end{array}$ & $\begin{array}{c}24 \\
22 \%\end{array}$ & $\begin{array}{c}55 \\
51 \% \\
\end{array}$ & $\begin{array}{c}15 \\
14 \% \\
\end{array}$ & $\begin{array}{c}7 \\
6 \% \\
\end{array}$ & $\begin{array}{c}6 \\
6 \% \\
\end{array}$ \\
\hline
\end{tabular}


Research as a generator of knowledge management

\begin{tabular}{|c|c|c|c|c|}
\hline 38 & 48 & 11 & 8 & 3 \\
$35 \%$ & $44 \%$ & $10 \%$ & $7 \%$ & $3 \%$ \\
\hline
\end{tabular}

Table 5: An Influence of the fourth industrial age: The Academics according to the knowledge creation through RESEARCH with PRACTICE

\begin{tabular}{|c|c|c|c|c|c|c|}
\hline \multirow{2}{*}{ Variable } & \multirow{2}{*}{ Indicators } & \multicolumn{5}{|c|}{ Frequency and \% } \\
\hline & & SA & $\mathbf{A}$ & $\mathbf{N}$ & DA & SD \\
\hline \multirow{8}{*}{ 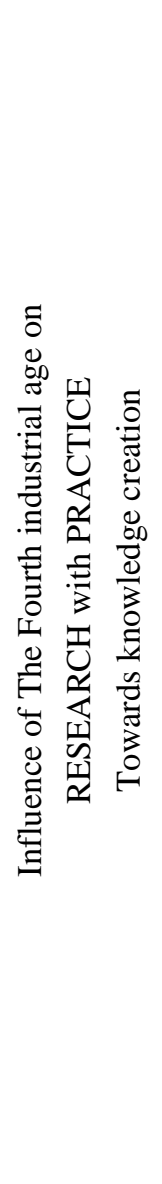 } & $\begin{array}{l}\text { Critical thinking stimulate students' to } \\
\text { provide them for knowledge creation } \\
\text { through research }\end{array}$ & $\begin{array}{c}50 \\
38.16 \%\end{array}$ & $\begin{array}{c}60 \\
45.80 \%\end{array}$ & $\begin{array}{c}17 \\
12.98 \%\end{array}$ & $\begin{array}{c}3 \\
2.29 \%\end{array}$ & $\begin{array}{c}1 \\
0.07 \%\end{array}$ \\
\hline & $\begin{array}{c}\text { Researchers as the most effective } \\
\text { workforce for the job market }\end{array}$ & $\begin{array}{c}60 \\
45.80 \% \\
\end{array}$ & $\begin{array}{c}49 \\
34.96 \% \\
\end{array}$ & $\begin{array}{c}29 \\
22.14 \% \\
\end{array}$ & $\begin{array}{c}0 \\
0 \% \\
\end{array}$ & $\begin{array}{c}0 \\
0 \%\end{array}$ \\
\hline & $\begin{array}{l}\text { Quality business research improves the } \\
\text { quality of university functions teaching }\end{array}$ & $\begin{array}{c}68 \\
51.90 \%\end{array}$ & $\begin{array}{c}47 \\
35.88 \%\end{array}$ & $\begin{array}{c}16 \\
12.22 \%\end{array}$ & $\begin{array}{c}0 \\
0 \%\end{array}$ & $\begin{array}{c}0 \\
0 \%\end{array}$ \\
\hline & $\begin{array}{l}\text { Is the knowledge-based views with } \\
\text { respect to research- teaching -learning } \\
\text { link }\end{array}$ & $\begin{array}{c}46 \\
35.11 \%\end{array}$ & $\begin{array}{c}42 \\
32.06 \%\end{array}$ & $\begin{array}{c}35 \\
26.71 \%\end{array}$ & $\begin{array}{c}7 \\
05.34 \%\end{array}$ & $\begin{array}{c}1 \\
0.07 \%\end{array}$ \\
\hline & $\begin{array}{l}\text { learning and teaching interact with } \\
\text { research methods and models in practice }\end{array}$ & $\begin{array}{c}53 \\
40.45 \%\end{array}$ & $\begin{array}{c}46 \\
35.11 \%\end{array}$ & $\begin{array}{c}27 \\
20.62 \%\end{array}$ & $\begin{array}{c}5 \\
03.82 \%\end{array}$ & $\begin{array}{c}0 \\
0 \%\end{array}$ \\
\hline & $\begin{array}{c}\text { Knowledge for business research } \\
\text { studying interact with teaching, research } \\
\text { and research practice }\end{array}$ & $\begin{array}{c}66 \\
50.38 \%\end{array}$ & $\begin{array}{c}48 \\
36.64 \%\end{array}$ & $\begin{array}{c}15 \\
11.44 \%\end{array}$ & $\begin{array}{c}1 \\
0.07 \%\end{array}$ & $\begin{array}{c}1 \\
0.07 \%\end{array}$ \\
\hline & $\begin{array}{l}\text { Model building and optimization } \\
\text { improve the quality of university } \\
\text { teaching and learning process for the job } \\
\text { market }\end{array}$ & $\begin{array}{c}72 \\
54.96 \%\end{array}$ & $\begin{array}{c}51 \\
38.93 \%\end{array}$ & $\begin{array}{c}8 \\
6.11 \%\end{array}$ & $\begin{array}{c}0 \\
0 \%\end{array}$ & $\begin{array}{c}0 \\
0 \%\end{array}$ \\
\hline & $\begin{array}{l}\text { Research improves the quality of } \\
\text { university teaching and learning process } \\
\text { for the job market }\end{array}$ & $\begin{array}{c}66 \\
50.38 \%\end{array}$ & $\begin{array}{c}55 \\
41.98 \%\end{array}$ & $\begin{array}{c}10 \\
7.63 \%\end{array}$ & $\begin{array}{c}0 \\
0 \%\end{array}$ & $\begin{array}{c}0 \\
0 \%\end{array}$ \\
\hline
\end{tabular}

Table 6: Influence of the fourth industrial age: The academics to knowledge creation through MBAM program transformation into business research process studying according to the job market

\begin{tabular}{|c|c|c|c|c|c|}
\hline \multirow{2}{*}{ Variable } & \multirow{2}{*}{ Indicators } & \multicolumn{2}{|c|}{ Total } & \multicolumn{2}{|c|}{ Total } \\
\hline & & Yes & $\%$ & No & $\%$ \\
\hline 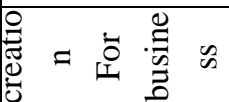 & $\begin{array}{l}\text { Transfer of research methods and models } \\
\text { knowledge to learners may be provided }\end{array}$ & 103 & 95 & 5 & 5 \\
\hline
\end{tabular}




\begin{tabular}{|c|c|c|c|c|}
\hline $\begin{array}{l}\text { through the teaching of research methods } \\
\text { and models }\end{array}$ & & & & \\
\hline $\begin{array}{l}\text { Business research views are respected to } \\
\text { research methods and models' building }\end{array}$ & 96 & 89 & 12 & 11 \\
\hline $\begin{array}{l}\text { Effective strategy for knowledge creation is } \\
\text { a model building research into teaching }\end{array}$ & 87 & 81 & 21 & 19 \\
\hline $\begin{array}{l}\text { Operation Research into teaching as a } \\
\text { knowledge transfer for job market }\end{array}$ & 80 & 74 & 28 & 26 \\
\hline $\begin{array}{l}\text { Teaching interact with new research } \\
\text { approaches studying }\end{array}$ & 80 & 74 & 28 & 26 \\
\hline All academics have to be good researchers & 65 & 60 & 43 & 40 \\
\hline $\begin{array}{l}\text { Knowledge of research methods and models } \\
\text { as a main for MBAM students }\end{array}$ & 88 & 81 & 20 & 19 \\
\hline $\begin{array}{l}\text { Interact through face-to-face settings to } \\
\text { disseminate business research knowledge }\end{array}$ & 88 & 81 & 21 & 19 \\
\hline $\begin{array}{l}\text { Research into teaching should not be a } \\
\text { separate process }\end{array}$ & 73 & 68 & 35 & 32 \\
\hline $\begin{array}{c}\text { Research Knowledge is a basis for all } \\
\text { students - certainly all graduates - have to } \\
\text { be researchers and managers }\end{array}$ & 55 & 51 & 53 & 49 \\
\hline $\begin{array}{l}\text { Business Research interacts with business } \\
\text { teaching }\end{array}$ & 87 & 81 & 21 & 19 \\
\hline $\begin{array}{l}\text { Research as a generator of knowledge } \\
\text { management }\end{array}$ & 84 & 78 & 24 & 22 \\
\hline $\begin{array}{c}\text { Business Research into teaching as a } \\
\text { knowledge transfer process }\end{array}$ & 87 & 81 & 21 & 19 \\
\hline $\begin{array}{l}\text { For MBAM teaching interact with research } \\
\text { modeling }\end{array}$ & 85 & 79 & 23 & 21 \\
\hline $\begin{array}{l}\text { Knowledge should flow from teaching to } \\
\text { research approaches }\end{array}$ & 82 & 76 & 26 & 24 \\
\hline $\begin{array}{l}\text { Critical thinking stimulate students' to } \\
\text { provide them for knowledge creation } \\
\text { through research }\end{array}$ & 66 & 61 & 42 & 39 \\
\hline $\begin{array}{l}\text { Researchers as the most effective workforce } \\
\text { for the job market }\end{array}$ & 75 & 69 & 33 & 31 \\
\hline $\begin{array}{l}\text { Quality business research improves the } \\
\text { quality of university functions teaching }\end{array}$ & 72 & 67 & 36 & 33 \\
\hline $\begin{array}{c}\text { Knowledge for business research studying } \\
\text { interact with teaching, research and research } \\
\text { practice }\end{array}$ & 88 & 81 & 20 & 19 \\
\hline
\end{tabular}




\begin{tabular}{|c|c|c|c|c|c|}
\hline & $\begin{array}{c}\text { An effective way of benefit is to link } \\
\text { business research in teaching and student- } \\
\text { centered Learning }\end{array}$ & 90 & 83 & 18 & 17 \\
\cline { 2 - 5 } & $\begin{array}{c}\text { Research improves the quality of university } \\
\text { teaching and learning process for the job } \\
\text { market }\end{array}$ & 92 & 85 & 16 \\
\hline
\end{tabular}

Table 7: An Influence of the fourth industrial age: Students according to knowledge creation through Business research methods and models TEACHING

\begin{tabular}{|c|c|c|c|c|c|c|}
\hline \multirow{2}{*}{ Variable } & \multirow{2}{*}{ Indicators } & \multicolumn{5}{|c|}{ Frequency and \% } \\
\hline & & SA & $\mathbf{A}$ & $\mathbf{N}$ & DA & SD \\
\hline \multirow{6}{*}{ 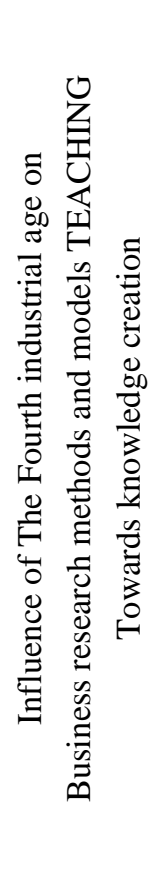 } & $\begin{array}{l}\text { Transfer of research methods and } \\
\text { models knowledge to learners may be } \\
\text { provided through the teaching of } \\
\text { research methods and models }\end{array}$ & $\begin{array}{c}70 \\
54.44 \%\end{array}$ & $\begin{array}{c}25 \\
19.10 \%\end{array}$ & $\begin{array}{c}15 \\
11.45 \%\end{array}$ & $\begin{array}{c}15 \\
11.45 \%\end{array}$ & $\begin{array}{c}5 \\
4.58 \%\end{array}$ \\
\hline & $\begin{array}{l}\text { Business research views are respected to } \\
\text { research methods and models' building }\end{array}$ & $\begin{array}{c}45 \\
34.35 \% \\
\end{array}$ & $\begin{array}{c}32 \\
24.43 \% \\
\end{array}$ & $\begin{array}{c}26 \\
19.85 \% \\
\end{array}$ & $\begin{array}{c}20 \\
15.27 \% \\
\end{array}$ & $\begin{array}{c}7 \\
6.11 \% \\
\end{array}$ \\
\hline & $\begin{array}{l}\text { Transfer of "model building" knowledge } \\
\text { to learners may be provided through } \\
\text { teaching and other mediums with } \\
\text { research and research practice }\end{array}$ & $\begin{array}{c}75 \\
57.25 \%\end{array}$ & $\begin{array}{c}30 \\
22.90 \%\end{array}$ & $\begin{array}{c}26 \\
19.85 \%\end{array}$ & $\begin{array}{c}0 \\
0 \%\end{array}$ & $\begin{array}{c}0 \\
0 \%\end{array}$ \\
\hline & $\begin{array}{l}\text { Models' building Knowledge views with } \\
\text { respect to research and decision making } \\
\text { teaching link }\end{array}$ & $\begin{array}{c}48 \\
36.64 \%\end{array}$ & $\begin{array}{c}28 \\
21.37 \%\end{array}$ & $\begin{array}{c}35 \\
26.72 \%\end{array}$ & $\begin{array}{c}10 \\
7.63 \%\end{array}$ & $\begin{array}{c}7 \\
6.11 \%\end{array}$ \\
\hline & $\begin{array}{c}\text { Transfer of business knowledge } \\
\text { responds to research methods and } \\
\text { models building }\end{array}$ & $\begin{array}{c}67 \\
51.14 \%\end{array}$ & $\begin{array}{c}19 \\
14.50 \%\end{array}$ & $\begin{array}{c}24 \\
18.32 \%\end{array}$ & $\begin{array}{c}12 \\
9.16 \%\end{array}$ & $\begin{array}{c}8 \\
6.87 \%\end{array}$ \\
\hline & $\begin{array}{l}\text { Business research have to respond to } \\
\text { business process optimization }\end{array}$ & $\begin{array}{c}36 \\
27.48 \%\end{array}$ & $\begin{array}{c}44 \\
33.59 \%\end{array}$ & $\begin{array}{c}42 \\
32.06 \%\end{array}$ & $\begin{array}{c}7 \\
5.34 \%\end{array}$ & $\begin{array}{c}1 \\
1.53 \%\end{array}$ \\
\hline
\end{tabular}

Table 8: An Influence of the fourth industrial age: Students according to knowledge creation through Business research methods and models LEARNING

\begin{tabular}{|c|c|c|c|c|c|c|}
\hline \multirow{2}{*}{ Variable } & \multirow{2}{*}{ Indicators } & \multicolumn{5}{|c|}{ Frequency and \% } \\
\hline & & SA & A & $\mathbf{N}$ & DA & SD \\
\hline \multirow{2}{*}{ 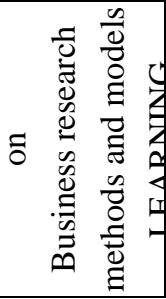 } & $\begin{array}{c}\text { Critical thinking stimulate students' to } \\
\text { provide them for research and } \\
\text { knowledge creation }\end{array}$ & $\begin{array}{c}47 \\
35.60 \%\end{array}$ & $\begin{array}{c}48 \\
36.64 \%\end{array}$ & $\begin{array}{c}20 \\
15.27 \%\end{array}$ & $\begin{array}{c}10 \\
7.63 \%\end{array}$ & $\begin{array}{c}5 \\
4.58 \%\end{array}$ \\
\hline & $\begin{array}{l}\text { Model building teaching is suggested by } \\
\text { many pedagogical researchers as the } \\
\text { most effective for MA student's learning }\end{array}$ & $\begin{array}{c}55 \\
41.98 \%\end{array}$ & $\begin{array}{c}49 \\
37.40 \%\end{array}$ & $\begin{array}{c}29 \\
22.14 \%\end{array}$ & $\begin{array}{c}5 \\
3.82 \%\end{array}$ & $\begin{array}{c}0 \\
0 \%\end{array}$ \\
\hline
\end{tabular}




\begin{tabular}{|c|c|c|c|c|c|}
\hline process & & & & & \\
\hline $\begin{array}{c}\text { Effective strategy for knowledge } \\
\text { creation is a model building research } \\
\text { into teaching }\end{array}$ & $\begin{array}{c}68 \\
51.90 \%\end{array}$ & $\begin{array}{c}37 \\
28.24 \%\end{array}$ & $\begin{array}{c}15 \\
12.21 \%\end{array}$ & $\begin{array}{c}0 \\
0 \%\end{array}$ & $\begin{array}{c}0 \\
0 \%\end{array}$ \\
\hline $\begin{array}{l}\text { Operation Research into teaching as a } \\
\text { knowledge transfer for job market }\end{array}$ & $\begin{array}{c}46 \\
35.11 \%\end{array}$ & $\begin{array}{c}42 \\
32.06 \%\end{array}$ & $\begin{array}{c}30 \\
22.90 \%\end{array}$ & $\begin{array}{c}9 \\
6.87 \%\end{array}$ & $\begin{array}{c}3 \\
3.05 \%\end{array}$ \\
\hline $\begin{array}{l}\text { Teaching interact with new research } \\
\text { approaches studying }\end{array}$ & $\begin{array}{c}33 \\
25.19 \%\end{array}$ & $\begin{array}{c}46 \\
35.11 \%\end{array}$ & $\begin{array}{c}29 \\
22.14 \%\end{array}$ & $\begin{array}{c}23 \\
17.56 \%\end{array}$ & $\begin{array}{c}0 \\
0 \%\end{array}$ \\
\hline $\begin{array}{c}\text { Business Research interacts with } \\
\text { business modeling }\end{array}$ & $\begin{array}{c}66 \\
50.38 \% \\
\end{array}$ & $\begin{array}{c}43 \\
32.82 \%\end{array}$ & $\begin{array}{c}15 \\
11.45 \%\end{array}$ & $\begin{array}{c}5 \\
4.58 \%\end{array}$ & $\begin{array}{c}1 \\
0.76 \%\end{array}$ \\
\hline $\begin{array}{l}\text { Business Research into teaching as a } \\
\text { business knowledge transfer process }\end{array}$ & $\begin{array}{c}72 \\
54.96 \% \\
\end{array}$ & $\begin{array}{c}51 \\
38.39 \% \\
\end{array}$ & $\begin{array}{c}8 \\
6.11 \% \\
\end{array}$ & $\begin{array}{c}0 \\
0 \% \\
\end{array}$ & $\begin{array}{c}0 \\
0 \% \\
\end{array}$ \\
\hline $\begin{array}{l}\text { Research into teaching should not be a } \\
\text { separate process }\end{array}$ & $\begin{array}{c}61 \\
46.56 \% \\
\end{array}$ & $\begin{array}{c}48 \\
36.64 \% \\
\end{array}$ & $\begin{array}{c}21 \\
16.79 \% \\
\end{array}$ & $\begin{array}{c}0 \\
0 \% \\
\end{array}$ & $\begin{array}{c}0 \\
0 \%\end{array}$ \\
\hline
\end{tabular}

Table 9: An Influence of the fourth industrial age: Students according to knowledge creation through RESEARCH APPROACHES

\begin{tabular}{|c|c|c|c|c|c|c|}
\hline \multirow{2}{*}{ Variable } & \multirow{2}{*}{ Indicators } & \multicolumn{5}{|c|}{ Frequency and \% } \\
\hline & & $\mathbf{S A}$ & A & $\mathbf{N}$ & DA & SD \\
\hline \multirow{7}{*}{ 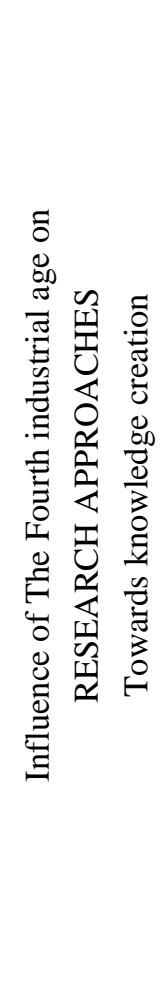 } & $\begin{array}{l}\text { Research Knowledge is a basis for all } \\
\text { students - certainly all graduates - have } \\
\text { to be researchers and managers }\end{array}$ & $\begin{array}{c}67 \\
51.14 \%\end{array}$ & $\begin{array}{c}33 \\
25.19 \%\end{array}$ & $\begin{array}{c}21 \\
16.03 \%\end{array}$ & $\begin{array}{c}15 \\
11.45 \%\end{array}$ & $\begin{array}{c}4 \\
3.82 \%\end{array}$ \\
\hline & $\begin{array}{c}\text { Knowledge of business research } \\
\text { studying interact with teaching } \\
\text { modeling, optimization and research } \\
\text { practice }\end{array}$ & $\begin{array}{c}48 \\
36.64 \%\end{array}$ & $\begin{array}{c}39 \\
29.77 \%\end{array}$ & $\begin{array}{c}24 \\
18.32 \%\end{array}$ & $\begin{array}{c}15 \\
11.45 \%\end{array}$ & $\begin{array}{c}4 \\
3.82 \%\end{array}$ \\
\hline & $\begin{array}{l}\text { A movement of knowledge to learners } \\
\text { may be provided through teaching and } \\
\text { other mediums with research and } \\
\text { practice }\end{array}$ & $\begin{array}{c}73 \\
55.72 \%\end{array}$ & $\begin{array}{c}32 \\
24.43 \%\end{array}$ & $\begin{array}{c}23 \\
17.56 \%\end{array}$ & $\begin{array}{c}3 \\
2.29 \%\end{array}$ & $\begin{array}{c}0 \\
0 \%\end{array}$ \\
\hline & $\begin{array}{c}\text { Quality business research studying } \\
\text { improves student's skills for the job } \\
\text { market }\end{array}$ & $\begin{array}{c}50 \\
38.17 \%\end{array}$ & $\begin{array}{c}27 \\
20.61 \%\end{array}$ & $\begin{array}{c}33 \\
25.19 \%\end{array}$ & $\begin{array}{c}12 \\
9.16 \%\end{array}$ & $\begin{array}{c}8 \\
6.87 \%\end{array}$ \\
\hline & $\begin{array}{l}\text { The teaching of Optimization interact } \\
\text { with business research }\end{array}$ & $\begin{array}{c}75 \\
57.25 \% \\
\end{array}$ & $\begin{array}{c}20 \\
15.27 \% \\
\end{array}$ & $\begin{array}{c}15 \\
11.45 \% \\
\end{array}$ & $\begin{array}{c}18 \\
13.74 \%\end{array}$ & $\begin{array}{c}2 \\
2.29 \%\end{array}$ \\
\hline & $\begin{array}{l}\text { All academics have to be good } \\
\text { researchers }\end{array}$ & $\begin{array}{c}67 \\
51.14 \% \\
\end{array}$ & $\begin{array}{c}38 \\
29.00 \% \\
\end{array}$ & $\begin{array}{c}21 \\
16.03 \% \\
\end{array}$ & $\begin{array}{c}10 \\
7.63 \% \\
\end{array}$ & $\begin{array}{c}0 \\
0 \% \\
\end{array}$ \\
\hline & $\begin{array}{c}\text { Research as a generator of knowledge } \\
\text { management }\end{array}$ & $\begin{array}{c}56 \\
42.75 \%\end{array}$ & $\begin{array}{c}32 \\
24.43 \%\end{array}$ & $\begin{array}{c}30 \\
22.90 \%\end{array}$ & $\begin{array}{c}11 \\
8.40 \%\end{array}$ & $\begin{array}{c}1 \\
1.53 \%\end{array}$ \\
\hline
\end{tabular}




\begin{tabular}{|c|c|c|c|c|c|}
\hline $\begin{array}{c}\text { Business Research into teaching as a } \\
\text { knowledge transfer process }\end{array}$ & $\begin{array}{c}49 \\
37.40 \% \\
\end{array}$ & $\begin{array}{c}38 \\
29.00 \% \\
\end{array}$ & $\begin{array}{c}33 \\
25.19 \% \\
\end{array}$ & $\begin{array}{c}8 \\
6.11 \% \\
\end{array}$ & $\begin{array}{c}4 \\
3.82 \% \\
\end{array}$ \\
\hline $\begin{array}{c}\text { Business modeling research into } \\
\text { teaching should not be a separate } \\
\text { process }\end{array}$ & $\begin{array}{c}21 \\
16.03 \%\end{array}$ & $\begin{array}{c}18 \\
13.74 \%\end{array}$ & $\begin{array}{c}41 \\
31.30 \%\end{array}$ & $\begin{array}{c}32 \\
24.43 \%\end{array}$ & $\begin{array}{c}8 \\
6.87 \%\end{array}$ \\
\hline $\begin{array}{l}\text { For MBAM teaching interact with } \\
\text { research modeling }\end{array}$ & $\begin{array}{c}60 \\
45.80 \%\end{array}$ & $\begin{array}{c}22 \\
16.79 \%\end{array}$ & $\begin{array}{c}45 \\
34.35 \%\end{array}$ & $\begin{array}{c}9 \\
6.87 \%\end{array}$ & $\begin{array}{c}4 \\
3.82 \%\end{array}$ \\
\hline $\begin{array}{l}\text { Knowledge should flow from teaching } \\
\text { to research approaches }\end{array}$ & $\begin{array}{c}60 \\
45.80 \%\end{array}$ & $\begin{array}{c}22 \\
16.79 \%\end{array}$ & $\begin{array}{c}45 \\
34.35 \%\end{array}$ & $\begin{array}{c}9 \\
6.87 \%\end{array}$ & $\begin{array}{c}4 \\
3.82 \%\end{array}$ \\
\hline $\begin{array}{l}\text { Research as a generator of knowledge } \\
\text { management }\end{array}$ & $\begin{array}{c}68 \\
51.90 \%\end{array}$ & $\begin{array}{c}41 \\
31.30 \%\end{array}$ & $\begin{array}{c}20 \\
15.27 \%\end{array}$ & $\begin{array}{c}2 \\
1.53 \%\end{array}$ & $\begin{array}{c}0 \\
0 \%\end{array}$ \\
\hline $\begin{array}{l}\text { Research Knowledge is a basis for all } \\
\text { students - certainly all graduates - have } \\
\text { to be researchers and managers }\end{array}$ & $\begin{array}{c}73 \\
55.72 \%\end{array}$ & $\begin{array}{c}32 \\
24.43 \%\end{array}$ & $\begin{array}{c}23 \\
17.56 \%\end{array}$ & $\begin{array}{c}3 \\
2.29 \%\end{array}$ & $\begin{array}{c}0 \\
0 \%\end{array}$ \\
\hline
\end{tabular}

Table 10: An Influence of the fourth industrial age: Students according to knowledge creation through seven RESEARCH with PRACTICE

\begin{tabular}{|c|c|c|c|c|c|c|}
\hline \multirow{2}{*}{ Variable } & \multirow{2}{*}{ Indicators } & \multicolumn{5}{|c|}{ Frequency and \% } \\
\hline & & SA & $\mathbf{A}$ & $\mathbf{N}$ & DA & SD \\
\hline \multirow{7}{*}{ 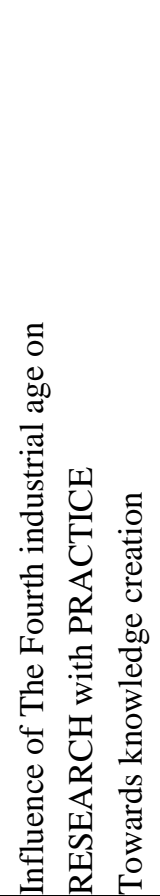 } & $\begin{array}{l}\text { Critical thinking stimulate students' to } \\
\text { provide them for knowledge creation } \\
\text { through research }\end{array}$ & $\begin{array}{l}50 \\
38.16 \%\end{array}$ & $\begin{array}{l}60 \\
45.80 \%\end{array}$ & $\begin{array}{l}17 \\
12.98 \%\end{array}$ & $\begin{array}{l}3 \\
2.29 \%\end{array}$ & $\begin{array}{l}1 \\
0.07 \%\end{array}$ \\
\hline & $\begin{array}{l}\text { Researchers as the most effective } \\
\text { workforce for the job market }\end{array}$ & $\begin{array}{l}60 \\
45.80 \%\end{array}$ & $\begin{array}{l}49 \\
34.96 \% \\
\end{array}$ & $\begin{array}{l}29 \\
22.14 \%\end{array}$ & $\begin{array}{l}0 \\
0 \%\end{array}$ & $\begin{array}{l}0 \\
0 \% \\
\end{array}$ \\
\hline & $\begin{array}{l}\text { Quality business research improves the } \\
\text { quality of university functions teaching }\end{array}$ & $\begin{array}{l}68 \\
51.90 \%\end{array}$ & $\begin{array}{l}47 \\
35.88 \%\end{array}$ & $\begin{array}{l}16 \\
12.22 \%\end{array}$ & $\begin{array}{l}0 \\
0 \%\end{array}$ & $\begin{array}{l}0 \\
0 \%\end{array}$ \\
\hline & $\begin{array}{l}\text { Is the knowledge-based views with } \\
\text { respect to research- teaching -learning } \\
\text { link }\end{array}$ & $\begin{array}{l}46 \\
35.11 \%\end{array}$ & $\begin{array}{l}42 \\
32.06 \%\end{array}$ & $\begin{array}{l}35 \\
26.71 \%\end{array}$ & $\begin{array}{l}7 \\
05.34 \%\end{array}$ & $\begin{array}{l}1 \\
0.07 \%\end{array}$ \\
\hline & $\begin{array}{l}\text { learning and teaching interact with } \\
\text { research methods and models in practice }\end{array}$ & $\begin{array}{l}53 \\
40.45 \%\end{array}$ & $\begin{array}{l}46 \\
35.11 \%\end{array}$ & $\begin{array}{l}27 \\
20.62 \%\end{array}$ & $\begin{array}{l}5 \\
03.82 \%\end{array}$ & $\begin{array}{l}0 \\
0 \%\end{array}$ \\
\hline & $\begin{array}{l}\text { Knowledge for business research } \\
\text { studying interact with teaching, research } \\
\text { and research practice }\end{array}$ & $\begin{array}{l}66 \\
50.38 \%\end{array}$ & $\begin{array}{l}48 \\
36.64 \%\end{array}$ & $\begin{array}{l}15 \\
11.44 \%\end{array}$ & $\begin{array}{l}1 \\
0.07 \%\end{array}$ & $\begin{array}{l}1 \\
0.07 \%\end{array}$ \\
\hline & Model building and optimization & 72 & 51 & 8 & 0 & 0 \\
\hline
\end{tabular}




\begin{tabular}{|l|l|l|l|l|l|l|}
\hline & $\begin{array}{l}\text { improve the quality of university } \\
\text { teaching and learning process for the job } \\
\text { market }\end{array}$ & $54.96 \%$ & $38.93 \%$ & $6.11 \%$ & $0 \%$ & $0 \%$ \\
\hline $\begin{array}{l}\text { Research improves the quality of } \\
\text { university teaching and learning process } \\
\text { for the job market }\end{array}$ & $\begin{array}{l}66 \\
50.38 \%\end{array}$ & $\begin{array}{l}55 \\
41.98 \%\end{array}$ & $\begin{array}{l}10 \\
7.63 \%\end{array}$ & $\begin{array}{l}0 \% \\
0 \%\end{array}$ & $\begin{array}{l}0 \% \\
0\end{array}$ \\
\hline
\end{tabular}

Table 11: Influence of the fourth industrial age: Students to knowledge creation through MBAM program transformation into business research process studying according to the job market

\begin{tabular}{|c|c|c|c|}
\hline \multirow{2}{*}{ Variable } & \multirow{2}{*}{ Indicators } & \multicolumn{2}{|c|}{ Percent } \\
\hline & & Yes & No \\
\hline \multirow{15}{*}{ 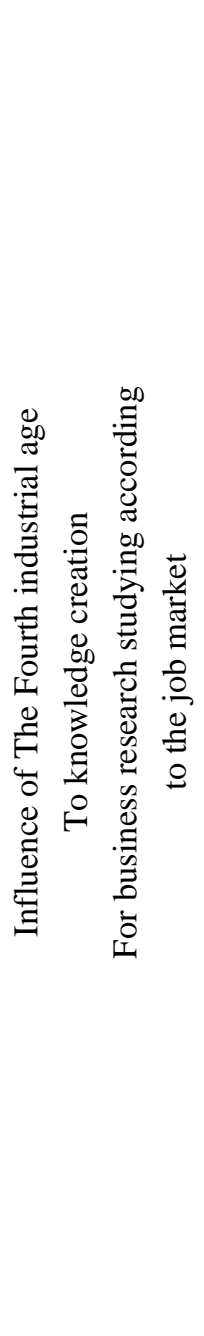 } & $\begin{array}{l}\text { Transfer of research methods and models } \\
\text { knowledge to learners may be provided through } \\
\text { the teaching of research methods and models }\end{array}$ & $\begin{array}{l}78.15 \\
80.15\end{array}$ & $\begin{array}{l}0.00 \\
0.00\end{array}$ \\
\hline & Business research views are respected to & 58.78 & 16.03 \\
\hline & research methods and models' building & 59.01 & 13.74 \\
\hline & Effective strategy for knowledge creation is a & 70.54 & 16.03 \\
\hline & model building research into teaching & 76.33 & 15.12 \\
\hline & $\begin{array}{l}\text { Operation Research into teaching as a } \\
\text { knowledge transfer for job market }\end{array}$ & 56.41 & 15.27 \\
\hline & $\begin{array}{l}\text { Teaching interact with new research approaches } \\
\text { studying }\end{array}$ & 72.52 & 16.03 \\
\hline & All academics have to be good researchers & 80.14 & 7.00 \\
\hline & $\begin{array}{l}\text { Knowledge of research methods and models as a } \\
\text { main for MBAM students }\end{array}$ & 67.18 & 9.93 \\
\hline & $\begin{array}{l}\text { Interact through face-to-face settings to } \\
\text { disseminate business research knowledge }\end{array}$ & 56.40 & 9.93 \\
\hline & $\begin{array}{l}\text { Research into teaching should not be a separate } \\
\text { process }\end{array}$ & 29.77 & 31.30 \\
\hline & $\begin{array}{c}\text { Research Knowledge is a basis for all students - } \\
\text { certainly all graduates - have to be researchers } \\
\text { and managers }\end{array}$ & 62.59 & 10.69 \\
\hline & $\begin{array}{l}\text { Business Research interacts with business } \\
\text { teaching }\end{array}$ & 52.59 & 10.69 \\
\hline & $\begin{array}{l}\text { Research as a generator of knowledge } \\
\text { management }\end{array}$ & 83.20 & 1.53 \\
\hline & $\begin{array}{l}\text { Business Research into teaching as a knowledge } \\
\text { transfer process }\end{array}$ & 58.78 & 21.38 \\
\hline
\end{tabular}




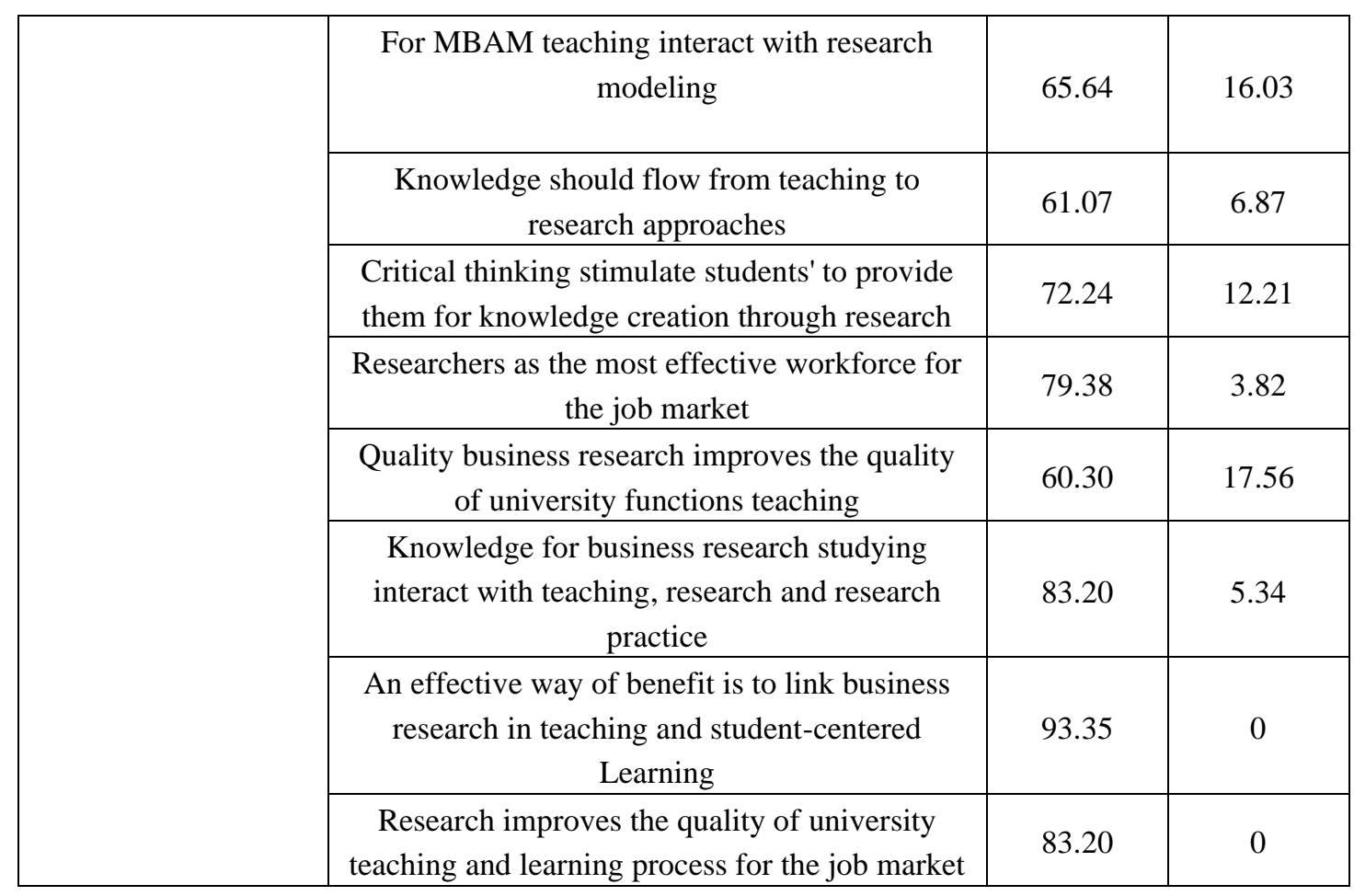

